\title{
OCCURRENCE, ABUNDANCE AND DISTRIBUTION OF BLEAK, COMMON SPIRLIN, AND SUNBLEAK IN THE ENVIRONMENTAL GRADIENTS OF SMALL RIVERS (TATARSTAN)
}

Arthur ASKEYEV*, Oleg ASKEYEV*, Igor ASKEYEV* and Sergey MONAKHOV*

* Tatarstan Academy of Sciences, Institute of Problems in Ecology and Mineral Wealth, Biomonitoring Laboratory, Daurskaya Street 28, Kazan, Tatarstan Republic, Russia, RU-420087, art.regulus@mail.ru, ORCID: 0000-0002-1214-7355, parus.cyanus@rambler.ru, ORCID: 0000-0001-6589-0479, archaeozoologist@yandex.ru, ORCID: 0000-0002-5304-4985, serega-28@inbox.ru.

DOI: 10.2478/trser-2021-0014

KEYWORDS: bleak, common spirlin, sunbleak, environmental factors, species.

ABSTRACT

The probability of occurrence, distribution, and abundance of bleak, common spirlin, and sunbleak in 316 small rivers of the Republic of Tatarstan were studied. The studied region has a high geographical and environmental heterogeneity. The impact of environmental factors on species occurrence was analyzed with generalized linear models. Among the selected fish, sunbleak had the highest probability of occurrence, and bleak had the highest abundance. Elevation was the only environmental variable significantly affecting the probability of occurrence of all three species. With an increase in elevation, the probability of occurrence of bleak, common spirlin, and sunbleak significantly decreased. Optimum values and niche breadth differed significantly between fish species for some of the environmental variables.

ZUSAMMENFASSUNG: Vorkommen, Abundanz und Verteilung von Ukelei, Gemeinem Spirlin und Moderlieschen in den Umweltgradienten kleiner Gewässer (Tatarstan).

Die Wahrscheinlichkeit des Vorkommens sowie der Verteilung und Abundanz von Ukelei, Spirlin und Moderlieschen wurden in 316 kleinen Flüssen der Republik Tatarstan untersucht. Die Untersuchungsregion hat eine hohe geographische Heterogenität, wie auch die Umwelt. Der Einfluss der Umweltfaktoren auf das Vorkommen der Arten wurde mithilfe generalisierter linearen Modelle analysiert. Unter den ausgewählten Fischen hat Moderlieschen die höchste Auftrittswahrscheinlichkeit, während Ukelei die höchste Abundanz hat. Die Höhenlage der Standorte war die einzige Umweltvariable, die das Vorkommen aller drei Fischarten wesentlich beeinflusste. Bei steigender Höhenlage nimmt die Wahrscheinlichkeit ihres Vorkommens von Ukelei, Spirlin und Moderlieschen deutlich ab. Die optimalen Werte sowie die Nischenbreite unterscheiden sich bei einigen Umweltvariablen wesentlich zwischen den untersuchten Fischarten.

REZUMAT: Ocurența, abundența și distribuția oblețului, beldiței și plevuștii în gradienții de mediu ai râurilor mici (Tatarstan).

$\mathrm{Au}$ fost studiate probabilitatea apariției, distribuției și abundenței oblețului, beldiței și plevuștii în 316 râuri mici din Republica Tatarstan. Regiunea studiată are o heterogenitate geografică și de mediu ridicată. Impactul factorilor de mediu asupra apariției speciilor a fost analizat cu modele liniare generalizate. Dintre peștii selectați, plevușca a avut cea mai mare probabilitate de apariție, iar oblețul a avut cea mai mare abundență. Altitudinea a fost singura variabilă de mediu care a afectat în mod semnificativ probabilitatea de apariție a tuturor celor trei specii. Odată cu creșterea altitudinii, probabilitatea de apariţie a oblețului, beldiței și plevuștii a scăzut semnificativ. Valorile optime și lățimea nișei au diferit semnificativ între speciile de pești pentru unele dintre variabilele de mediu. 


\section{INTRODUCTION}

Information on the occurrence, distribution, abundance and ecological preferences of various taxa of living organisms in the era of global climate change (Buisson et al., 2013; Comte et al., 2013; IPCC, 2014; Askeyev et al., 2020) is necessary for monitoring the state of various ecosystems, rational use of biological resources, and for the preservation of rare and endangered species. It is important to know which environmental factors limit the distribution, occurrence, and number of species, as well as what is their optimum ecological niche in terms of environmental factors. Knowledge of these ecological variables of the biocenosis is important for understanding the functional role of biota in ecosystems and can be used in bioindication of the state of aquatic ecosystems. In modern times, rivers are among the ecosystems most disturbed by humans (Brookes et al., 1983; Gregory, 2006). Rivers are often used as reservoirs, sources of energy supply, places of passage for navigable transport, places for tourism and recreation, and for wastewater discharge (Brookes et al., 1983; Gregory, 2006). All these factors, acting together with climate change, can lead to extremely negative consequences, including the decreasing or the disappearance of entire populations of various species from bodies of water (Buisson et al., 2013; Bănăduc et al., 2021).

The Republic of Tatarstan has a relatively high taxonomic diversity of fish species (Kuznetsov, 2005; Askeyev et al., 2015, 2017), which have different preferences for environmental factors. In the current study, we selected the following fish species (Fig. 1): bleak - Alburnus alburnus (Linnaeus, 1758), common spirlin - Alburnoides bipunctatus (Bloch, 1782) (the species is listed in the Red Book of the Republic of Tatarstan, 2016), and sunbleak - Leucaspius delineatus (Heckel, 1843). These species have a common PontoCaspian origin (Nikolsky, 1974; Kuznetsov 2005), have a relatively close genetic relationship, are close in morphological size and live together in bodies of water within the studied region. In this regard, it would be interesting to know if there are differences between these fish species in preferences for environmental factors in small rivers of the Republic of Tatarstan.

The main objectives of the study were: (1) to estimate the current occurrence and abundance of fish, (2) to identify environmental factors affecting the probability of occurrence of bleak, common spirlin, and sunbleak, and (3) to calculate the optimum points and widths of the ecological niches for the main environmental factors.

\section{MATERIAL AND METHODS}

\section{Study area}

The Republic of Tatarstan is southeast of the Russian Plain. It is within the northern part of the Middle Volga region, at the confluence of the Volga and Kama rivers, and includes two natural zones - forest and forest-steppe (Minnikhanov, 2005).

The total area of the Republic of Tatarstan is $67,800 \mathrm{~km}^{2}$. In latitude, the republic occupies a middle position in the European part of Russia between $53^{\circ} 58^{\prime} \mathrm{N}$ and $56^{\circ} 40^{\prime} \mathrm{N}$, in longitude it is between $47^{\circ} 15^{\prime} \mathrm{E}$ and $54^{\circ} 15^{\prime} \mathrm{E}$ (Minnikhanov, 2005). This location determines the significant severity and continentality of the climate. Average annual temperatures range from $2.0-7.0^{\circ} \mathrm{C}$, with average monthly temperatures from $-14^{\circ} \mathrm{C}$ to $-12.1^{\circ} \mathrm{C}$ in January and $19^{\circ} \mathrm{C}$ to $21^{\circ} \mathrm{C}$ in July (Minnikhanov, 2005). 


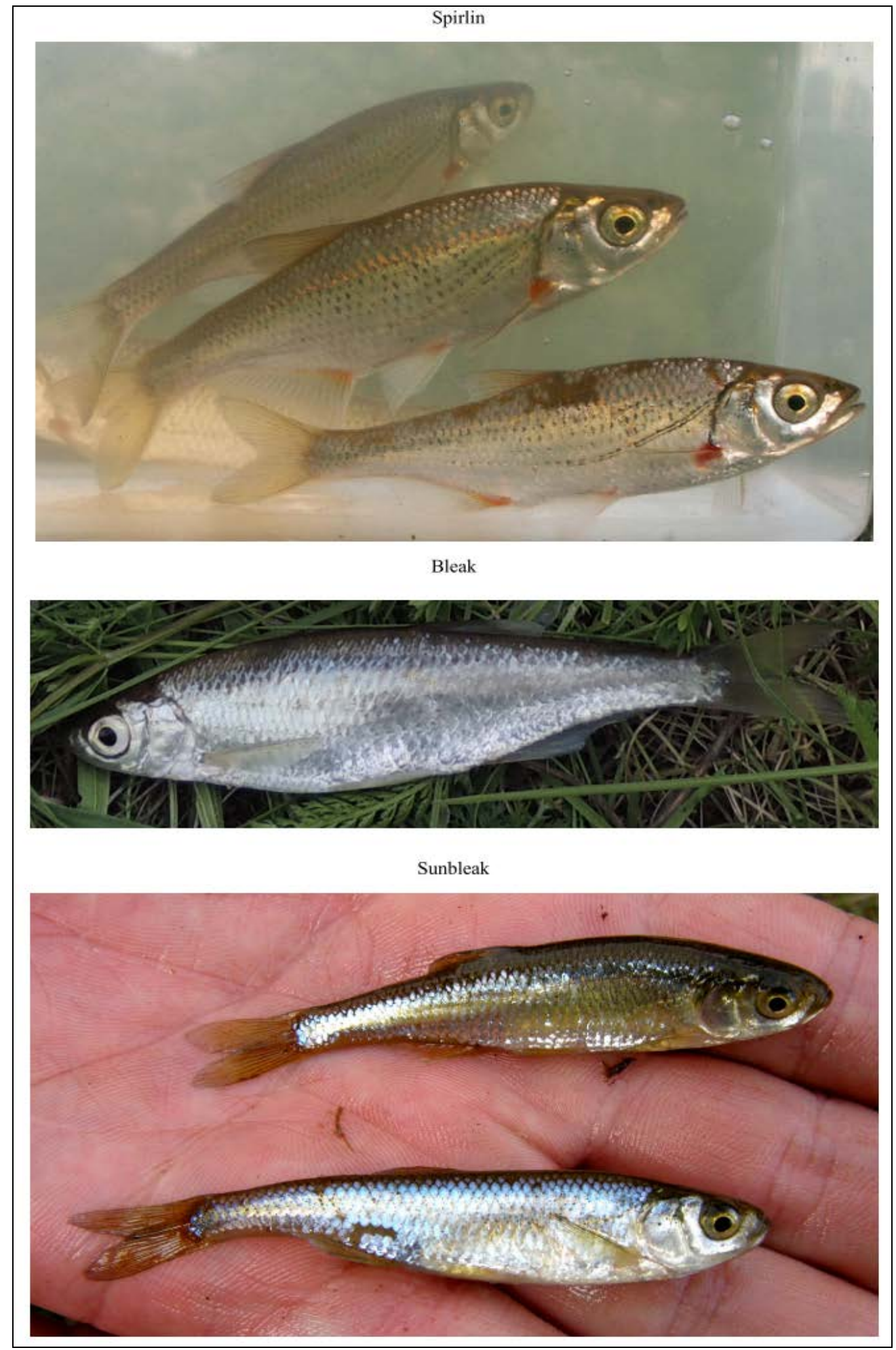

Figure 1: Photos of the investigated species of fish. 
We focused on the fish assemblages of small rivers (length up to $500 \mathrm{~km}$ ). We excluded rivers impacted by large reservoirs. Fish sampling was conducted at 316 locations (Fig. 2). The following seven environmental variables were obtained for each site: elevation (altitude) above sea level (from 53.2 to $270 \mathrm{~m}$, mean $105.5 \mathrm{~m}$, SD-standard deviation $39.1 \mathrm{~m}$ ), mean width (from 0.5 to $55 \mathrm{~m}$, mean $7.7 \mathrm{~m}$, SD $10.3 \mathrm{~m}$ ), mean depth (from 0.15 to $1.7 \mathrm{~m}$, mean $0.71 \mathrm{~m}$, SD $0.31 \mathrm{~m}$ ), water velocity (from zero to one m/s, mean $0.31 \mathrm{~m} / \mathrm{s}$, SD $0.16 \mathrm{~m} / \mathrm{s}$ ), trees/bush cover along banks (from zero to $100 \%$, mean $47.9 \%$, SD $27.5 \%$ ), dominant bottom substrate ( 1 - mud, 2 - clay or peat, 3 - sand, 4 - gravel, 5 - small pebbles, 6 - large stones up to $150 \mathrm{~mm}, 7$ - large stones $150-300 \mathrm{~mm}, 8$ - boulders $>300 \mathrm{~mm}$ ) and human impacts (as a 7 point scale, 0 - no agriculture or forestry, 1 - light agricultural impact - hayfields, weak grazing and forestry at a distance of 0-250 m from the river bank, 2 - moderate agricultural impact - average grazing at a distance of $0-250 \mathrm{~m}$ from the river bank, the presence of a ford and a watering hole for livestock, 3 - strong agricultural impact - strong grazing with cattle driving trails visible, arable land, and sheds for animals at a distance of 0-250 m from the river bank, 4 - moderate agriculture impact and oil pollution - average grazing, and mining of oil and gas at a distance of $0-250 \mathrm{~m}$ from the river bank, 5 - urban impact - river site in town or big village, 6 - strong oil and chemical pollution - chemical or oil odor is felt and seen).

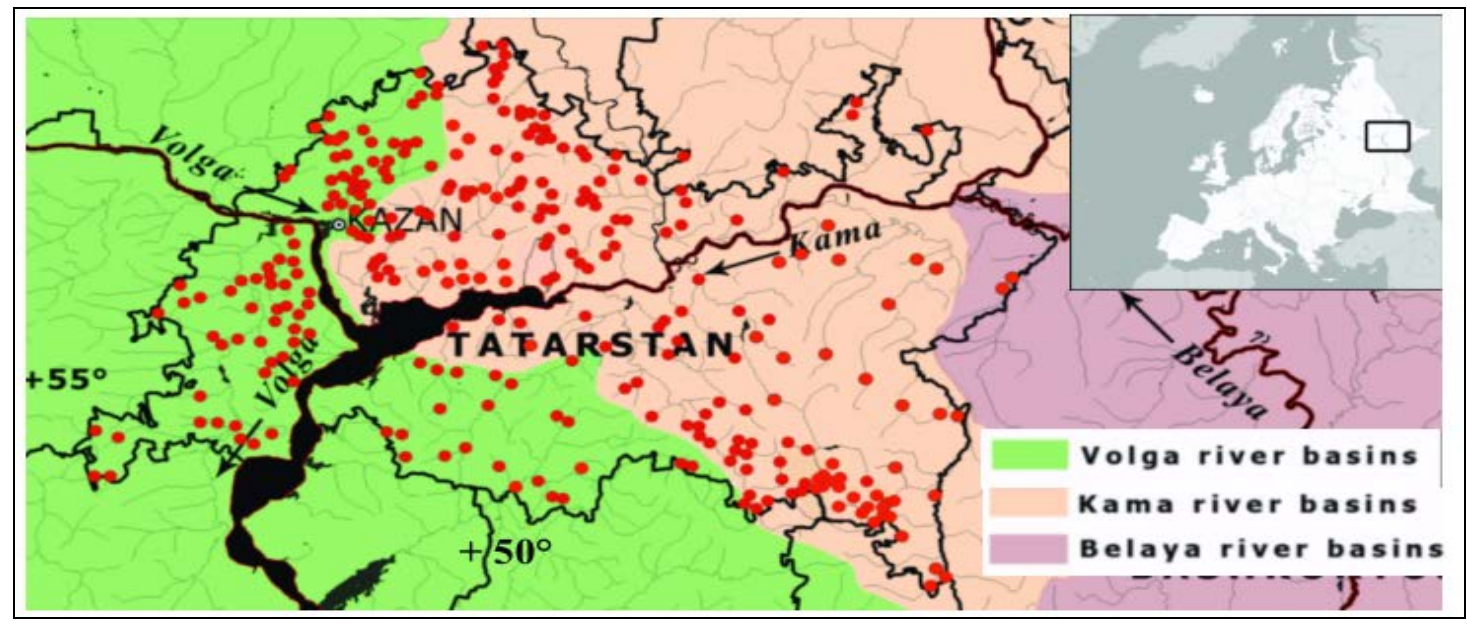

Figure 2: Distribution of the sampling sites in the Tatarstan (location within Europe).

\section{Fish assemblage data}

Fieldwork was carried out from May to October 2010-2020 during reduced summer flows. Fish samples were collected during active wading catches of similar duration (60 min.). In smaller rivers, four people fished by seining and dip netting across the full width of the river. Two people, one at each end, pulled the seine through the water until they reached the shore, beaching the seine on dry ground. We used three lengths of nets, depending on the width of the river: $5-15 \mathrm{~m}$ in length, $1.2-1.5 \mathrm{~m}$ high, $5 \times 5 \mathrm{~mm}$ mesh in the wings, $3 \times 3 \mathrm{~mm}$ in bags. Dip nets were of diameter 50-70 cm, with 4 x $4 \mathrm{~mm}$ mesh. Lengths of between $200 \mathrm{~m}$ (smaller rivers) and $400 \mathrm{~m}$ (larger rivers) of the river sites were sampled. For determining the length of the site, we followed the recommendations for catching fish by FAME Consortium (2004). Caught fish were placed in a plastic basin, identified, counted, and measured at the end of each catch session. After each session $\geq 90 \%$ of fish were returned to the water. Identification of fish was carried out according to Maitland and Linsell (2009) and Makeeva et al. (2011). For each site, we calculated the occurrence and abundance of each fish species. 


\section{Data analysis}

Relationship between fish species and environmental variables

For each of the three fish species the nature and strength of relationships with the seven environmental parameters was examined using binary logistic regression with the environmental variables as predictors. Only statistically significant variables were retained in these regressions. To assess the accuracy of the final models, we used the area under the ROC curve (AUC), which indicates the predictive performance expressed as an index ranging from 0.5 to 1 . The accuracy of the model was interpreted after Swets (1988) as follows: $0.90-1.00$ excellent; 0.80-0.90 good; 0.70-0.80 fair; 0.60-0.70 poor; 0.50-0.60 fail.

Species optimums and niche breadth

Species optimums in terms of fish numbers for each environmental variable were calculated in order to rank species by habitat preferences. This model fits Gaussian response models to species abundances along an environmental gradient. The fitted parameters are optimum (i.e. average) and niche breadth/tolerance (i.e. standard deviation). The algorithm is based on weighted averaging (ter Braak and van Dam, 1989).

Calculation and visualization were done in PAST version 4.04 and XLSTAT 2021.

\section{RESULTS AND DISCUSSION}

Probability of occurrence of bleak, common spirlin and sunbleak in the rivers of the Republic of Tatarstan and other regions of Europe

Sunbleak had the highest probability of occurrence (31\%), followed by bleak (26\%), and common spirlin (9\%); they inhabit all large river basins in the study area. During the study period, 3,483 bleak individuals were caught (mean 11; SD 39.7); 1,777 individuals of sunbleak (mean 5.6; SD 42.4), and 809 individuals of common spirlin (mean 2.6; SD 14.7).

The probability of occurrence of sunbleak in the Republic of Tatarstan is much higher than elsewhere in Europe. In France, the frequency of occurrence of this species is $18.6 \%$ (Maire et al., 2016), in Hungary 5.5\% (Saly et al., 2011), in northeastern Germany - 3\% (Fieseler and Wolter, 2006), and in Lithuania 3\% (Stakenas, 2002).

The probability of occurrence of bleak in European rivers varies greatly, but in general it is lower than in the Republic of Tatarstan. For example, the probability of occurrence of this species in France was 39.7\% (Maire et al., 2016), in Hungary 22\% (Saly et al., 2011), in Lithuania 16\% (Stakenas, 2002), in central France 13\% (Pont et al., 2005), in northeastern Germany 12\% (Fieseler and Wolter, 2006), but in the Udava River in Slovakia it is rare (Pekarik et al., 2011). In Romania it is a relatively spread species from the submontaneous lotic sectors to their end (Bănărescu, 1964) abundant in some of them like Târnava and Timiş rivers (Bănăduc, 2005; Bănăduc et al., 2013a), and rare in others like Iza, Cibin, and Olteț rivers (Bănăduc, 1999, 2000, 2013b).

In some places, such as Romania common spirlin it is a relatively spread species in the Carpathian uper to middle lotic sectors (Bănărescu, 1964) abundant in some of the rivers like Târnava Mare and Olteţ rivers (Bănăduc, 2005; Bănăduc et al., 2013), France (Maire et al., 2016), and in the Udava River of Slovakia (Pekarik et al., 2011); elsewhere, such as in the Czech Republic, it is rare (Lusk and Pivnicka, 2009), also in Romania in Vişeu and Târnava Mică (Staicu et al., 1998; Bănăduc, 2005). In some river basins in Western Europe it is completely absent (Santoul et al. 2005; Fieseler and Wolter, 2006; Saly et al., 2011).

Such a difference in the probability of occurrence of bleak, common spirlin, and sunbleak between river basins in different parts of Europe may be due to phylogeographic characteristics, as well as genetic and ecological differences in the populations. 
Distribution of bleak, common spirlin, and sunbleak in environmental gradients in small rivers of the Republic of Tatarstan. Relationship between fish species and environmental variables.

The probability of occurrence for each fish species had statistically significant relationships with three or more of the environmental variables (Tab. 1). The probability of occurrence of three species was associated with elevation, two species with the substrate and width of the river, and water velocity, forest cover, and river depth were associated with one species. The probabilities of occurrence of bleak and of sunbleak were associated with three environmental variables, and common spirlin with four variables (Tab. 1). All final models had satisfactory predictive power (AUC) varying from 0.784 to 0.888 (Tab. 1).

Table 1: Coefficients and model summary for models summarizing the relationship between presence/absence of fish and environmental variables. Species arranged in decreasing order of frequency.

\begin{tabular}{|c|c|c|c|c|c|c|c|c|c|}
\hline Species & Constant & Cover & $\begin{array}{c}\text { Ele- } \\
\text { vation }\end{array}$ & Depth & $\begin{array}{c}\text { Sub- } \\
\text { stratum }\end{array}$ & Velocity & Width & AIC & AUC \\
\hline Sunbleak & 1.51 & - & -8.36 & - & -0.33 & -1.69 & - & 378.4 & 0.784 \\
\hline $\begin{array}{c}\text { Bleak } \\
\text { Common }\end{array}$ & 1.52 & -1.14 & -3.50 & - & - & - & 0.16 & 241.6 & 0.888 \\
\hline spirlin & -4.64 & - & -2.11 & 1.99 & 0.69 & - & 4.13 & 155.6 & 0.845 \\
\hline
\end{tabular}

The impact of elevation on populations and on individual fish species has been well studied in different parts of the world (Huet, 1959; Sanders and Rahbek, 2012; CarvajalQuintero et al., 2015; Askeyev et al., 2017; Cheng et al., 2019; Ponomarev and Loskutova, 2020). In our current research, elevation had a significant negative effect on all fish species (Tab. 1). Figure 3 clearly illustrates the decrease probability of occurrences of all species in elevation gradient. The probability of occurrences of bleak and common spirlin was close to zero at elevations above $150 \mathrm{~m}$ (Fig. 3). These results once again confirm that elevation is the main environmental variable affecting fish species. 
Common spirlin and bleak had increased probability of occurrence in wide rivers (Tab. 1). This species' preference for large rivers is noted in other parts of Europe (Kesminas and Vibrickas, 2000; Lusk and Pivnicka, 2009). Bleak avoids sites with a high forest cover (Tab. 1). This species prefers open sites; shading prevents this species from feeding effectively. In our study, sunbleak avoided sites of rivers with "hard" substrates (Tab. 1), since they are not suitable for this species as a substrate for spawning. Common spirlin had opposite preferences for substrate; its probability of occurrence increased in rivers with gravel and stones and great depths (Tab. 1). The common spirlin's preference for sandy-rocky substrates and relatively large depths is also noted in Târnava River watershed (Curtean-Bănăduc et al., 2019). Our studies have once again confirmed the fact that sunbleak, being a limnophil species, prefers areas with low velocity (Tab. 1). Human impact did not significantly affect the probability of occurrence for any of the selected species.

Higher probability of occurrences of sunbleak in comparison with bleak and common spirlin is associated with broader distribution by elevation and indifference to the width and depth gradients of the river, which allows this species to inhabit different sites of the rivers.

\section{Species optimums and niche breadth}

Table 2 shows the optimal points and breadths in the gradient of the environmental variables, which can be interpreted as the position of the realized niche and its width. Unfortunately, these optimum and niche ranges are not directly comparable with those in the literature because the latter were typically estimated using presence-absence data.

Comparing the optimum points between study species, we can say that they vary greatly (Tab. 2). For example, from sunbleak with an optimum point in altitude at $92.1 \mathrm{~m}$, to bleak at $74.6 \mathrm{~m}$. In contrast, in terms of river width (Tab. 2, Fig. 4), bleak had the largest optimum among the studied fish species, while sunbleak had the smallest, the difference between these species was more than $20 \mathrm{~m}$ (Tab. 2, Fig. 4). Common spirlin had the highest optimum of tree/bush cover and of water velocity. Sunbleak had an optimum to water velocity only half that of common spirlin (Tab. 2). The optimum points in depth for bleak and common spirlin were more than one $\mathrm{m}$, while that for sunbleak was almost $0.5 \mathrm{~m}$ less than bleak (Tab. 2).

The width of the ecological niche between species was also significantly different in some variables (Tab. 2). The greatest difference between species was observed in river width (Fig. 4) and tree/bush cover. The niche breadth of sunbleak for river width was only 4.7 $\mathrm{m}$, while common spirlin was $10.3 \mathrm{~m}$, and bleak $18.3 \mathrm{~m}$ (Fig. 4). Bleak had the widest niche in four out of five environmental factors, which may explain its highest abundance among the selected fish species. But even within the same species, we see that there are strong differences in the values of the width of the ecological niche to different environmental factors. For example, common spirlin had the widest ecological niche in terms of tree/bush cover, while it has the narrowest in terms of elevation and river depth. This proves once again that the rational protection of various types of living organisms is perhaps satisfactorily carried out only when analyzing the effects of all environmental factors on occurrence and abundance. 


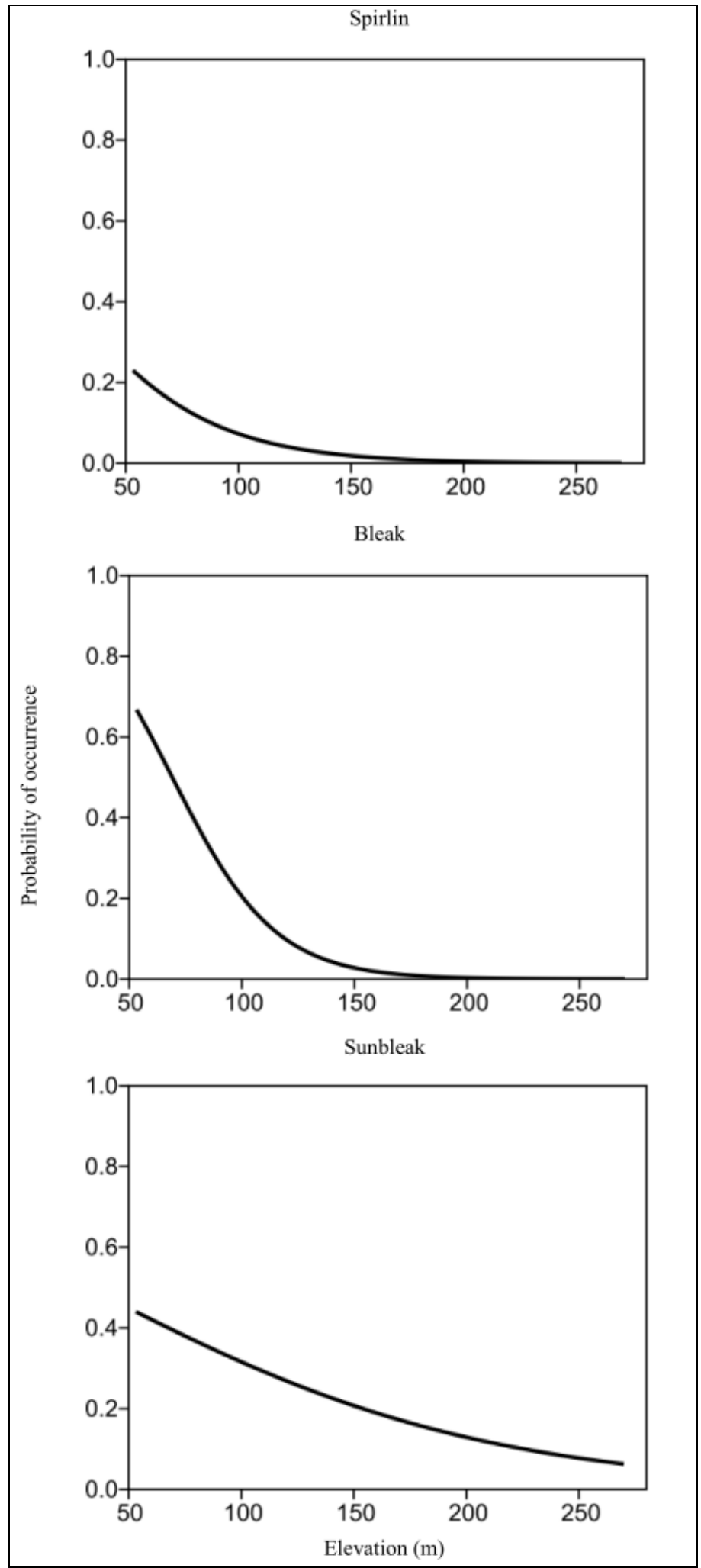

Figure 3: Relationship between the probability of occurrence of fish species and elevation. 


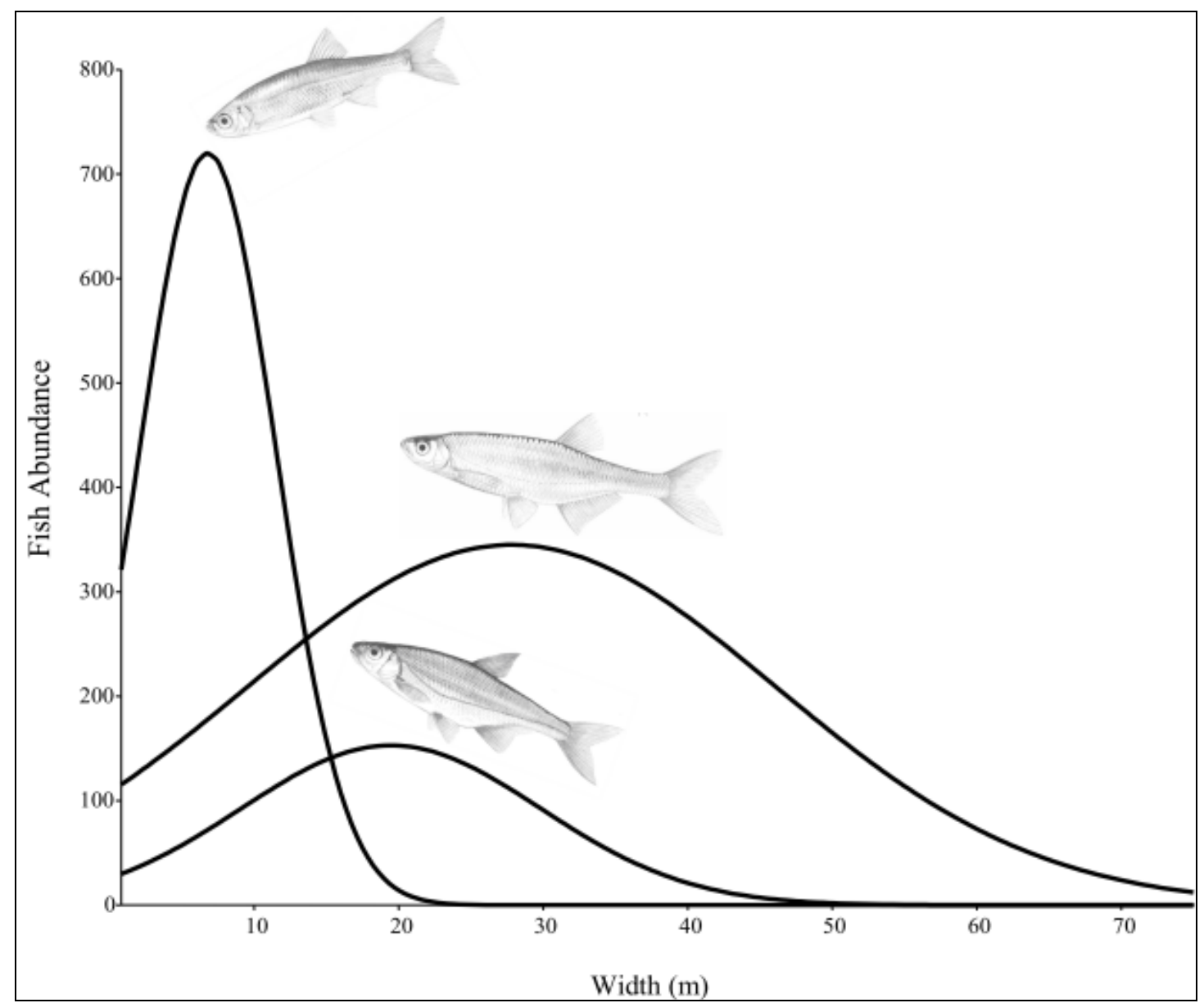

Figure 4: Distribution optimums and niche breadth of fish species by width of the river.

Table 2: Fish species optimum values and tolerance (niche breadth) against five environmental variables (based on abundance data).

\begin{tabular}{|c|c|c|c|}
\hline Environmental factors & Bleak & Common spirlin & Sunbleak \\
\hline \multicolumn{4}{|c|}{ Optimum values } \\
\hline Elevation (m) & 74.6 & 83.0 & 92.1 \\
\hline Width (m) & 27.8 & 19.5 & 6.8 \\
\hline Cover tree/bush (\%) & 38.7 & 52.9 & 45.0 \\
\hline Velocity (m/s) & 0.33 & 0.43 & 0.21 \\
\hline Depth (m) & 1.15 & 1.06 & 0.67 \\
\hline \multicolumn{4}{|c|}{ Tolerance (niche breadth) } \\
\hline Elevation (m) & 18.6 & 13.4 & 15.7 \\
\hline Width (m) & 18.3 & 10.3 & 4.7 \\
\hline Cover tree/bush (\%) & 21.8 & 35.2 & 19.0 \\
\hline Velocity (m/s) & 0.14 & 0.12 & 0.10 \\
\hline Depth (m) & 0.30 & 0.26 & 0.27 \\
\hline
\end{tabular}




\section{CONCLUSIONS}

Our data, obtained on a large and heterogeneous territory in the east of the European continent, showed both differences and similarities in reaction models in relatively closely related fish species. Once again, the significant impact of the elevation gradient on the occurrence of different fish species has been shown. The state of the populations of the common spirlin - a rare and endangered species listed in the Red Data Book of the Republic of Tatarstan - does not cause serious concerns at this point in time in the study area. Small rivers are refugee for the preservation of the common spirlin. But the present climate change could have a serious negative impact on this rare fish. Therefore, further monitoring of the abundance and occurrence of the common spirlin should be carried out especially carefully. Based on the results of our work, a protected natural area was created, which includes a site of the river, which is characterized by a high abundance of the common spirlin.

\section{ACKNOWLEDGEMENTS}

We thank Lily and Madina Askeyeva for their unstinting help in organizing logistics for the field surveys. We thank Dmitry Akhmetzyanov for revising the text of the early drafts of the manuscript. Our special thanks to Professor Tim Sparks for revising the English of the final drafts of the manuscript. 


\section{REFERENCES}

1. Askeyev O., Askeyev I., Askeyev A., Monakhov S. and Yanybaev N., 2015 - River fish assemblages in relation to environmental factors in the eastern extremity of Europe (Tatarstan Republic, Russia), Environmental Biology of Fishes, 98, 1277-1293.

2. Askeyev A., Askeyev O., Yanybaev N., Askeyev I., Monakhov S., Marić S. and Hulsman K., 2017 - River fish assemblages along an elevation gradient in the eastern extremity of Europe, Environmental Biology of Fishes, 100, 585-596.

3. Askeyev O., Askeyev A. and Askeyev I., 2020 - Rapid climate change has increased postbreeding and autumn bird density at the eastern limit of Europe, Ecological Research, 35, 235242.

4. Bănăduc D., 1999 - Longitudinal zonation of the Iza River (Maramureş, Romania) according to the ichthyofauna, Travaux du Museum National d'Histoire naturelle Grogore Antipa, XLI, Bucureşti, 527-537.

5. Bănăduc D., 2000 - Ichthyofaunistic criteria for Cibin River (Transylvania, Romania) human impact assesment, Travaux du Museum National d'Histoire naturelle Grigore Antipa, XLII, Bucureşti, 365-372.

6. Bănăduc D., 2005 - Fish associations - habitats quality relation in the Târnave rivers ecological assessment, Transylvanian Review of Systematical and Ecological Research, 2, Edit. Universităţii "Lucian Blaga” din Sibiu, ISSN 1841-7051, ISBN 973-739-141-1, 123-136.

7. Bănăduc D., Stroilă V. and Angela-Curtean Bănăduc, 2013a - The fish fauna of the Timiş River (Banat, Romania), Transylvanian Review of Systematical and Ecological Research, 15 - special issue The Timiş River Basin, Edit. Universităţii "Lucian Blaga” din Sibiu, ISSN 1841-7051, 145-172.

8. Bănăduc D., Mărginean M. and Curtean-Bănăduc A., 2013b - Geographical and human impact elements influence on the fish fauna of the Olteţ River (Romania), Transylvanian Review of Systematical and Ecological Research, 15.2, The Wetlands Diversity, Edit. Universităţii "Lucian Blaga” din Sibiu, ISSN 1841-7051, 9-44.

9. Bănăduc D., Sas A., Cianfaglione K., Barinova S. and Curtean-Bănăduc A., 2021 - The role of aquatic refuge habitats for fish, and threats in the context of climate change and human impact, during seasonal hydrological drought in the Saxon Villages area (Transylvania, Romania), Atmosphere, 12, 1209, doi.org/10.3390/atmos12091209.

10. Bănărescu P. M., 1964 - Fauna Republicii Populare Române, Pisces-Osteichthyes, XIII, Edit. Academiei Republicii Populare Române, 959.

11. Brookes A., Gregory K., and Dawson F., 1983 - An assessment of river channelization in England and Wales, Science of The Total Environment, 27, 97-111.

12. Buisson L., Grenouillet G., Villéger S., Canal J. and Laffaille P., 2013 - Toward a loss of functional diversity in stream fish assemblages under climate change, Global Change Biology, 19, 387-400.

13. Carvajal-Quintero J. D., Escobar F., Alvarado F., Villa-Navarro F. A., Jaramillo-Villa Ú. and Maldonado-Ocampo J. A., 2015 - Variation in freshwater fish assemblages along a regional elevation gradient in the northern Andes, Colombia, Ecology and Evolution, 5, 2608-2620.

14. Cheng D., Zhao X., Song J., Sun H., Wang S., Bai H. and Li Q., 2019 - Quantifying the distribution and diversity of fish species along elevational gradients in the Weihe River basin, northwest China, Sustainability, 11, 6177.

15. Comte L. and Grenouillet G., 2013 - Do stream fish track climate change? Assessing distribution shifts in recent decades, Ecography, 36, 1236-1246.

16. Curtean-Bănăduc A., Cismaş I. C. and Bănăduc D., 2019 - Management elements for two Alburninae species, Alburnus alburnus (Linnaeus, 1758) and Alburnoides bipunctatus (Bloch, 1782) based on a decision-support system study case, Transylvanian Review of Systematical and Ecological Research, 21, 81-92. 
17. Fieseler C. and Wolter C., 2006 - A fish-based typology of small temperate rivers in the northeastern lowlands of Germany, Limnologica, 36, 2-16.

18. Gregory K., 2006 - The human role in changing river channels, Geomorphology, 79, 172-191.

19. Huet M., 1959 - Profiles and biology of western European streams as related to fish management, Transactions of the American Fisheries Society, 88, 155-163.

20. Kesminas V. and Virbickas T., 2000 - Application of an adapted index of biotic integrity to rivers of Lithuania, Hydrobiologia, 422, 257-270.

21. Kuznetsov V., 2005 - Fish of the Volga-Kama region, Kazan, Idel-Press, 208. (in Russian)

22. Lusk S. and Pivnicka K., 2009 - Fish assemblages in the Czech Republic - species saturation. Frequency and changes along the longitudinal stream gradient, Acta Universitatis Environmentalica 1, P, 45-68.

23. Maire A., Laffaille P., Maire J. and Buisson, L., 2016 - Identification of priority areas for the conservation of stream fish assemblages: implications for river management in France, River Research and Applications, 234, 524-537.

24. Maitland P. and Linsell K., 2009 - Atlas of Fishes (a guide to freshwater fish species in Europe), translated and supplemented by Sideleva V. Amphora, St. Petersburg, 287. (in Russian)

25. Makeeva A., Pavlov D. and Pavlov D., 2011 - Atlas of juveniles of freshwater fish of Russia, Moscow, Partnerships of scientific publications KMK, 383. (in Russian)

26. Minnikhanov R. N., (ed.) 2005 - Atlas of the Republic of Tatarstan, edited by Moscow: production cartographic association “cartography”, 215. (in Russian)

27. Nikolsky G., 1974 - Fish ecology, Moscow, Vysshaya shkola, 367. (in Russian)

28. Pekarik L., Svatora M. and Kosco J., 2011 - Longitudinal structures of fish assemblages in a minimally disturbed stream, Biologia, 66, 886-893.

29. Ponomarev V. and Loskutova O., 2020 - Effect of elevation gradient on the structure of aquatic communities in the Vangyr River basin, the Subpolar Urals, Russian Journal of Ecology, 51, 72-81.

30. Pont D., Hugueny B. and Oberdorff T., 2005 - Modelling habitat requirement of European fishes: do species have similar responses to local and regional environmental constraints? Canadian Journal of Fisheries and Aquatic Sciences, 62, 1, 163-173.

31. Red Book of Republic of Tatarstan, 2016 - Kazan, Idel-Press, 760. (in Russian)

32. Saly P., Takacs P., Kiss I., Bíró P. and Erős T., 2011 - The relative influence of spatial context and catchment and site-scale environmental factors on stream fish assemblages in a humanmodified landscape, Ecology of Freshwater Fish, 20, 251-262.

33. Sanders N. and Rahbek C., 2012 - The patterns and causes of elevational diversity gradients, Ecography, 35, 1-3.

34. Santoul F., Cayrou J., Mastrorillo S. and Cereghino R., 2005 - Spatial patterns of the biological traits of fresh water fish communities in south-west France, Journal of Fish Biology, 66, 301314.

35. Staicu G., Bănăduc D. and Găldean N., 1998 - The structure of some benthic macroinvertebrates and fishes communities in the Vişeu Watershed, Maramureş, Romania, Travaux du Museum National d Histoire naturelle Grigore Antipa, XL, Bucureşti, 587-608.

36. Stakenas S., 2002 - Habitat use by 0+ fishes in small rivers of Lithuania, Acta Zoologica Lituanica 12, 30-41.

37. Swets J., 1988 - Measuring the accuracy of diagnostic systems, Science, 240, 1285-1293. ter Braak C. and van Dam H., 1989 - Inferring $\mathrm{pH}$ from diatoms: a comparison of old and new calibration methods, Hydrobiologia, 178, 209-223. 